\title{
Does Acquisition Improve Indonesian Bank Financial Performance?
}

\author{
Yutrizal Jacoub ${ }^{1 *}$, Dedi Budiman Hakim ${ }^{1 *}$, Sri Hartoyo1, \\ IPB Business School \\ Bogor Agricultural University \\ Bogor, Indonesia \\ Perdana Wahyu Santosa ${ }^{2}$ \\ Universitas Yarsi, \\ Jakarta, Indonesia \\ *corresponding authors \\ Email: yutrizal@yahoo.com,dedihakim@apps.ipb.ac.id
}

\section{ABSTRACT}

\begin{abstract}
The purpose of this study was to examine the differences in the financial performance of Indonesian banks before and after the acquisition during the period 2002-2017. There were 41 merger and acquisition transactions during this period conducted by foreign and domestic investors/banks. The analysis of this study was conducted on two groups, the first group is a sample of bank acquisitions conducted by foreign investors/banks, and the second group is a sample of bank acquisitions conducted by domestic investors/banks. Samples collected from 24 local private banks, which were acquisitions in the period 2002-2017. Data from annual reports and bank publications derived from the Financial Services Authority (OJK). Statistical Methods used in this study were descriptive statistics, t-test, and Wilcoxon Test. Empirical evidence has shown that in both sample groups, credit quality improved. However, in the sample group of cross-border acquisitions, there was also an improvement in management compliance with regulatory regulations where the minimum reserve requirement increased, while the capital adequacy ratio increased only for banks that were acquired by domestic investors/banks.
\end{abstract}

\section{Keywords: before and after the acquisition, cross-border, and domestic}

\section{Introduction}

Banking mergers and acquisitions have increased in Indonesia since 2002, mergers and acquisitions commonly grouped into two types; the first type is cross-border acquisitions, namely the acquisition of private banks by foreign investors/banks, and domestic acquisitions, namely the acquisition of private banks by domestic investors/banks. There were 41 bank acquisition transactions in Indonesia in the period 2002-2017, which included 31 cross-border acquisitions and ten domestic acquisitions. The peak of bank acquisitions in Indonesia occurred in 2007 and 2016. There were ten bank acquisitions in 2007, consisting of 8 cross-border acquisitions and two domestic acquisitions. In 2016, there were five bank acquisitions, four cross-border acquisitions, and one domestic acquisition. Foreign acquisition of banks (cross-border) involves investors and consortium of banks from Singapore, Malaysia, Australia, South Korea, Japan, India, China, Taiwan, Qatar, the Netherlands, and Britain, so that there is a shift in ownership of local private banks to foreign ownership.

There are several reasons why foreign investors and banks are interested in acquiring banks in Indonesia. The reasons are because of the limited business development and growth potential in their home country and the Indonesian banking market has high economic growth potential. Indonesia is a vast developing country with a population of more than 250 million people, with a rapidly growing middle class. The growth of the banking sector in Indonesia and the ASEAN region far exceeds the growth of banks in other regions such as Europe, the United States of America, the Middle East, and Africa. Banking in Indonesia also has a relatively high Net Interest Margin (NIM) appeal compared to banks in the ASEAN region. The acquisition expected to have a spillover effect on improving the performance, capability, competitiveness, and structure of the Indonesian banking industry. 


\title{
International Journal of Business and Applied Social Science
}

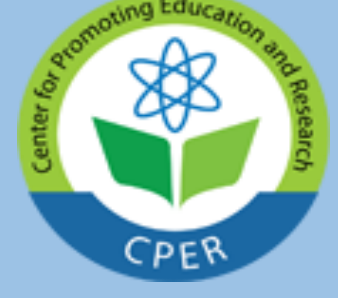

\author{
E-ISSN: 2469-6501 \\ VOL: 6, ISSUE: 3 \\ March/2020
}

DOI:10.33642/ijbass.v6n3p5

https://ijbassnet.com/

Opportunities for foreign investment to enter the banking industry are even higher with the integration of financial and banking markets in the ASEAN region called the ABIF (ASEAN Banking Integration Framework) that planned implemented in 2020. ABIF aims banks in ASEAN that meet the criteria as an ASEAN Qualified Banks (AQB) can access potential markets that are outside the country of origin and improve operational flexibility by opening broad access to banks originating from the ASEAN region. With the market potential, which is still growing and the implementation of ABIF 2020, this not only attracts the attention of regional banks to invest in Indonesia but also foreign banks outside the ASEAN region. In the domestic bank acquisition group, there have been ten acquisitions from 2002-2017. Domestic acquisitions are driven by the desire of local banks to enter and develop a new business line to gain economies of scope. The domestic bank was acquiring some banks such as Bank Jasa Artha, Bank Awaguna, Bank Persyarikatan, and Bank Utama Internasional to be converted into Islamic commercial banks.

Ahmad et al. (2007) explained that domestic investors or banks tend to have preferences to target banks with good financial performance characteristics, such as profitability performance. Other researchers, Alam and Ng (2013), add that domestic banks tend to prioritize banks with good cost or efficiency performance, while foreign banks tend to prioritize external variables (industrial environment). Other researchers such as Cyree (2010), Fathony (2012), Kaur and Kaur (2013), and Sufian and Kamarudin (2015) in their study stated that bank size is also important for investors because bank size can affect the ability of banks to make efficiency, and is related with the market reach that can be reached by a bank (Hernando $\boldsymbol{e t}$ al. 2009). This research will examine in detail related to the acquisition activities in the banking industry in Indonesia and to examine the differences in the financial performance of Indonesian banks before and after the acquisition during the period 2002-2017.

\section{Literature Review}

Al-Hroot et al. (2017) explained that investors and bank management expect improvement in financial performance after the acquisition because acquisition considered can enhance bank competitiveness and expand the banking market share. According to Al-Qudaiby and Muhammad (2014), through the acquisition of banks, it can create value for stakeholders by increasing profits, on the other hand, the acquisition also expected to encourage management to collaborate, including in the exchange of resources and capabilities, so that it will improve efficiency (Pasiouras, Gaganis, and Zopounidis 2008; ElBannan 2015). Acquisitions encourage synergy between managers, thereby encouraging banks to operate on economies of scale (AlQudaiby and Muhammad 2014).

Through acquisitions, acquired banks have the opportunity to improve efficiency and productivity through sharing knowledge and control from investors (Pradipta and Zaharias 2016, Sufian and Majid 2007). The investors (acquirer banks) support the improvement of the acquired bank's performance. According to Santoso (2010), if the acquired bank consolidates with a bank that has a high-efficiency score, the result will be that the acquired bank will have better efficiency.

Mergers and acquisitions expected to increase Capital Adequacy Ratio (CAR), where collaboration between investors and acquired banks makes management better in dealing with operational risks; in this case, the management expected to increase fund reserves to anticipate these risks (Anthony 2017). In terms of asset quality and Statutory Reserves (GWM) is predicted to increase after the acquisition, it happens because additional capital from investors makes the acquired banks better able to meet the minimum statutory deposit requirements by regulations from Bank Indonesia and the Financial Services Authority (Mulyana 2012).

Cahyarini and Pustikaningsih (2017) research results show that merger and acquisition activities can significantly increase profitability ratios proxied from the Return on Equity (ROE) and Net Interest Margin (NIM) variables. The target bank's ability to increase its ability to earn profits projected to increase after the acquisition because the acquiring bank expected to collaborate with the acquired bank in several ways, such as increasing the amount of cash flow for business development (Coyle 2000; Weston and Weaver 2001), taking control in company management so that it can operate better and more efficiently (Coyle 2000), or increase competitiveness through diversification, conglomeration, and market share expansion (Tripathi and Lamba 2015). 
Loan to Deposit Ratio (LDR) ) projected to decrease because banks tend to delay credit expansion and focus more on improving performance. Also, regulation on credit expansion at banks that have low performance can strengthen of merger and acquisition impact on LDR (Mulyana 2012). The NPL ratio expected to decline due to improved performance by management and temporary suspension of credit expansion carried out by the target bank expected to improve in terms of handling bad credit risk (Mulyana 2012). The NPL ratio expected to decline due to improved performance by management and temporary suspension of credit expansion carried out by the target bank expected to improve in terms of handling bad credit risk. Based on the arguments above, the acquisition expected to improve the acquirer bank's and the target bank's performance. This increase of performance expected to occur in financial performance, such as asset quality and liquidity, where additional capital from investors expected to have a significant effect in improving asset quality and liquidity.

\subsection{Hypothesis}

1. Credit quality (NPL ratio), efficiency (BOPO), liquidity (LDR), and sensitivity to market risk (commitment gap) decreased after the acquisition.

2. Capital adequacy (CAR), management compliance with regulatory provisions (minimum reserve requirement), profitability (ROE, and NIM) increased after the acquisition.

\section{Research Method}

The research method is descriptive statistical analysis, where parametric statistics used for normally distributed data and non-parametric analysis used when data not normally distributed. The parametric statistic that used is the paired sample $\mathrm{t}$ difference test, while the non-parametric statistic that used is the Wilcoxon test, with an alpha level at $10 \%$.

\section{The followings are:}

\section{a. Paired sample t difference test:}

Where:

$$
t_{\text {value }}=\frac{\bar{x}_{1}-\bar{x}_{2}}{\sqrt{\frac{s_{1}^{2}}{n_{1}}+\frac{s_{2}^{2}}{n_{2}}-2 r\left(\frac{s_{1}}{\sqrt{n_{1}}}\right)\left(\frac{s_{2}}{\sqrt{n_{2}}}\right)}}
$$

$\bar{x}_{1}=$ mean after acquisition

$\bar{x}_{2}=$ mean before acquisition

$s_{1}^{2}=$ variance after acquisition

$s_{2}^{2}=$ variance before acquisition

$n_{1}=$ total no. of samples after acquisition

$n_{2}=$ total no. of samples before acquisition

$r=$ correlation between after and before acquisition

\section{b. Wilcoxon test:}

Where:

$$
z=\frac{T-\left[\frac{1}{4 n(n+1)}\right]}{\sqrt{1 / 24(n)(n+1)(2 n+1)}}
$$

$\mathrm{T}=$ the smallest value difference between after and before acquisition

$\mathrm{n}=$ total no. of samples

\subsection{Bank's Performance Analysis}

Performance analysis used to assess the performance of a company (bank) at a particular time by comparing the performance (before and after) or comparing the performance plan with the realization. Performance analysis is not only 
needed for investors but also regulators. In Indonesia, regulators conduct performance analysis, one of them using the CAMELS approach (capital, assets, management, earnings, liquidity, and sensitivity to market risks) by Bank Indonesia Regulation (PBI) no. 6/10/PBI/2004 dated 12 April 2004 concerning the Rating System for Banks, to control risks arising from banking activities, to create security and soundness in the banking system (Gandapradja 2004).

Capital, assets, management, earnings, liquidity, and sensitivity to risks (CAMELS) are the most influential aspects of the bank's financial condition, thus affecting the health of the bank, following is the description:

- Capital: banks must have sufficient capital and have reserves to anticipate risks or losses due to bank activities.

- Assets: banks must have good asset quality and reflect market valuation; also, the bank requires having an evenly distributed investment portfolio.

- Management: banks' management must be competent and have high integrity to apply bank risk management principles so that banks can minimize that risk exposure.

- Earnings: banks must have quality and stability of revenues and efficient in managing their resources. The bank must also establish clear profit targets for the future.

- Liquidity: banks must have the ability to meet their obligations, where banks are required to have a level of liquidity so that banks can meet obligations and mitigate interest rate risk exposure.

- Sensitivity to market risks: banks must pay attention to extreme changes that may occur in the market, the extent to which banks can survive in these conditions.

\subsection{Variables and Measurement}

The following are the variables and its measurement used in this study (Table 1):

\section{Table 1. List of the variables and its measurement}

\begin{tabular}{|c|c|c|}
\hline Variable & Measurement & Data type \\
\hline $\begin{array}{l}\text { Non-Performing Loans (NPL) Ratio NPLs are non- } \\
\text { performing loans or risks from credit collectibility by } \\
\text { measure debt that classified as substandard, doubtful } \\
\text { or bad }\end{array}$ & NPL $=$ Non-Performing Loans / Total Loans & Ratio \\
\hline $\begin{array}{l}\text { Operating Expenses per Operating Income (BOPO) } \\
\text { Ratio BOPO ratio shows the ability of companies to } \\
\text { produce cost efficiency by measure operational cost } \\
\text { compared to the revenue generated. }\end{array}$ & $\begin{array}{l}\mathrm{BOPO}=\text { Operational Expenses / Operating } \\
\text { Expenses }\end{array}$ & Ratio \\
\hline $\begin{array}{l}\text { Loan to Deposits Ratio (LDR) Ratio LDR is the ratio } \\
\text { of total financing compared to third party funds } \\
\text { received by banks (Deposit) }\end{array}$ & LDR $=$ Total Loans $/$ Total Third Party Funds & Ratio \\
\hline Commitment Gap & $\begin{array}{l}\text { Commitment Receivable - Commitment } \\
\text { Liabilities }\end{array}$ & Ratio \\
\hline $\begin{array}{l}\text { Capital Adequacy Ratio (CAR) is capital used by } \\
\text { banks to carry out operational activities and as a } \\
\text { buffer if a loss occurs }\end{array}$ & $\begin{array}{l}\text { CAR = Capital Tier } 1+\text { Capital Tier } 2 \text { / Risk } \\
\text { Weighted Assets }\end{array}$ & Ratio \\
\hline Statutory Reserve Requirement (GWM) & $\begin{array}{l}\text { Reserve on Indonesia Central Bank / Third } \\
\text { Party Funds }\end{array}$ & Ratio \\
\hline $\begin{array}{l}\text { Return on Equity (ROE) ROE shows the rate of } \\
\text { return made by the company to shareholders. }\end{array}$ & ROE $=$ Net Profit After Tax / Total Equity & Ratio \\
\hline $\begin{array}{l}\text { Net Interest Margin (NIM) NIM shows the compared } \\
\text { to the bank's productive assets }\end{array}$ & $\begin{array}{l}\text { NIM }=(\text { Interest income-Interest expense }) / \\
\text { Average Productive Assets }\end{array}$ & Ratio \\
\hline
\end{tabular}




\section{Results and Discussion}

\subsection{Differences in Bank Financial Performance After and Before the Acquisition (Cross-border and Domestic Acquisition)}

In general, the performance of the CAR, NPL, GWM, LDR, and Commitments Gap variable experienced significant changes after the acquisition compared to before the acquisition. CAR, GWM, LDR ratios and Commitment Gap increased, while the NPL ratio and NIM ratio decreased according to table 2. The results of the two paired-sample tests supported by the results of descriptive statistical analysis, which seen from a comparison of the average value of performance after and before the acquisitions.

Capital Adequacy Ratio (CAR), which is the ratio of a bank's capital in relation to its risk-weighted assets and current liabilities. The two paired-sample difference tests conducted to all sample groups, and the result is obtained t-value of 1.769 and is significant at a five percent significance level. The average CAR after the acquisition increased to 26.85 percent from 20.03 percent (before the acquisition). The bank's capital ratio (CAR) after the acquisition is higher than before the acquisition. The acquired bank has stronger capital after the acquisition than before the acquisition. Stronger capital accrued because the capital injection from investors is higher than the increase in assets after the acquisition. After the acquisition, the acquiring bank will provide additional and sufficient capital that can be used by the acquired bank for business expansion and is useful to cover risks arising from the business activities of the acquired bank, such as anticipating credit risk and other productive assets of the bank and strengthening the bank capital structure. After the acquisitions and capital injection, new shareholders take strategic actions to strengthen the management team that expected to bring changes and improve bank performance, new shareholders will review the bank's productive asset portfolio, improve credit systems and procedures, as well as authority and credit approval limits.

Table 2. The combined sample test on performance after and before the acquisition

\begin{tabular}{|c|c|c|c|c|c|c|c|}
\hline \multirow{2}{*}{ Variabel } & \multicolumn{2}{|c|}{ Mean } & \multirow{2}{*}{ Mean Gap } & \multirow{2}{*}{ t-value } & \multirow{2}{*}{ z-value } & \multirow{2}{*}{ p-value } & \\
\hline & After & Before & & & & & \\
\hline CAR (\%) & 26.85 & 20.03 & 6.82 & 1.769 & - & 0.046 & $* *$ \\
\hline NPL (\%) & 3.36 & 6.79 & -3.43 & -2.173 & - & 0.021 & $* *$ \\
\hline GWM (\%) & 8.94 & 7.24 & 1.7 & 1.952 & - & 0.032 & $* *$ \\
\hline ROE (\%) & 2.43 & -0.69 & 3.12 & 0.765 & - & 0.227 & \\
\hline NIM (\%) & 4.95 & 6.08 & -1.13 & -2.681 & - & 0.007 & $* * *$ \\
\hline BOPO (\%) & 95.4 & 105.98 & -10.58 & - & -0.061 & 0.476 & \\
\hline LDR (\%) & 98.8 & 77.78 & 21.02 & 2.688 & - & 0.007 & $* * *$ \\
\hline GAP (IDR mn) & -4622777.2 & -864392.19 & -3758385.01 & - & -3.619 & 0.000 & $* * *$ \\
\hline
\end{tabular}

Significant at the $\alpha$ level: ${ }^{* *} 5$ percent, and ${ }^{* * *} 1$ percent.

Non-performing Loan (NPL) ratio, which is the ratio between low-quality loans and the amount of credit disbursed by banks. The NPL ratio after acquisition in this combined sample was tested with two paired samples to analyze the difference before and after the acquisition, and test result obtained t-value of -2.173 , significant at a five percent significance level. The average NPL decreased after the acquisition to 3.36 percent from before the acquisition of 6.79 percent. The improvement in NPL performance occurred in both the combined, cross-border, and domestic groups of samples. These results indicate a real difference in the ratio of quality of credit assets (NPLs) of acquired banks between after and before acquisitions. The bank NPL ratio after the acquisition is smaller than before acquisition. These results are also in line with the study of Amelia and Ika (2014), where obtain empirical findings results of a five percent significance level for combined samples and a 10 percent significance level for samples of cross-border and domestic acquisitions. After the acquisition of the bank, with the support of the holding company and new management, various strategic actions took place, including improving credit quality and risk management, improving credit application procedures and processes, and credit approval. With the injection of capital from 


\title{
International Journal of Business and Applied Social Science
}

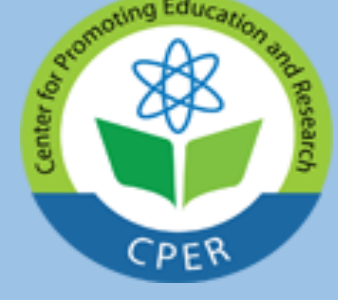

\author{
E-ISSN: 2469-6501 \\ VOL: 6, ISSUE: 3 \\ March/2020
}

DOI:10.33642/ijbass.v6n3p5

https://ijbassnet.com/

new shareholders, allowing banks to be more expansive in lending so that credit growth increases compared to before the acquisition.

The bank, after the acquisition, has capital flexibility from the injection of investor funds to improve management and product development. It expected that from this activity, there would be growth in third party funds that can distribute to lending and reduce the NPL ratio. The ability of banks to reduce bad loans is one of the results of investor management control over acquired banks so that banking performance can be improved by decreasing the NPL ratio. This study results in line with the results of research by Pradipta and Zaharias (2016) and Sufian and Majid (2007).

Fulfillment of Statutory Reserves (GWM) is the performance of management on compliance with regulatory provisions. The GWM ratio of the combined samples was tested with two paired samples to analyze the difference before and after the acquisition, and the test result obtained t-value 1.952, significant at a five percent significance level. These results give empirical evidence that the statistical mean difference of the reserve requirement for bank acquisitions between after and before the acquisition. The average reserve requirement of banks after the acquisition increased to 8.94 percent from before the acquisition of 7.24 percent. Capital contributions from new shareholders followed by an increase in the performance of thirdparty funds from the public that was collected by the bank allow the bank to be able to increase the reserve requirement in the central bank by the regulations. The acquisition causes the investor to provide additional capital to the acquired bank through the acquisition of the bank's shares. The capital is used by acquired banks, one of which is as additional funds for minimum mandatory deposits (Mulyana 2012). Increasing bank capital can increase the trust of customers and the public. In this case, the increase in reserve requirement will increase the trust of the public and customers to banks because they have smaller liquidity risk. However, if the capital owned tends to be fixed, and the bank raises the value of its reserve requirement, then this mechanism is used by banks to increase liquidity and reduce the ability of banks to extend credit. One of the reasons behind this is that investors wanted to focus on improving bank performance by evaluating lending activities, risk analysis, and improving bad credit performance.

Return on Equity (ROE) ratio is the return on bank equity. The ROE ratio of the combined samples was tested with two paired samples to analyze the difference before and after the acquisition, and the test result obtained t-value of 0.765 , significant at a five percent significance level. Where this result shows that there was no significant change in ROE performance between after and before the acquisition. These results explain that although there has been an average increase in ROE from - 0.69 percent before the acquisition to 2.43 percent after the acquisition, this improvement is not statistically significant. Improved profitability performance after the acquisition, statistically has not been proven to have direct implications for the improvement in the ROE of the acquired banks. These results are similar to Aprilita, Tjandrakirana, and Aspahani (2013) studies, where ROE after and before acquisition did not differ significantly. After making a capital deposit, the new shareholders will continue to form a new management team that will make various efforts to transform the bank's business so that it can produce better financial performance and expected to increase ROE. However, according to Marzuki and Widyawati (2013), the main motive of banks in conducting acquisitions is not because of economic motives, but noneconomic motives. These motives include the motive to enlarge the size of the company and improve management skills. In the long term, new economic benefits will emerge if the two or more companies succeed in synergizing in conducting their business activities (Marzuki and WIdyawati 2013). In terms of capacity building, the acquisition target bank will obtain additional funds from the acquiring bank.

The NIM ratio is a measure of the performance of net interest margins obtained by banks. The NIM ratio of the combined samples was tested with two paired samples to analyze the difference before and after the acquisition, and the test result obtained t-value -2.681 , significant at a one percent significance level. The average NIM ratio of banks after the acquisition decreased to 4.95 percent from before the acquisition of 6.08 percent. The decrease in NIM after the acquisition occurred because of a downward trend in interest rates after the acquisition resulting in a decrease in bank interest margins. Responding to the decline in margins, banks anticipated it by increasing credit volume growth and increasing the acquisition of non-interest income, such as from investment management and customer funds (wealth management, payment transactions, and savings administration fees). Changes in the banking NIM ratio are not only influenced by business activities and bank policies but also influenced by the economy and macroeconomic direction of a country. In Indonesia, the government 
encourages banks to reduce lending rates so that more people can access credit. Slowing economic growth will affect the rate of bank credit growth, which has an impact on decreasing income and bank interest margins. With the acquisition, investors will be directly involved in efforts to improve management, placing the best people who expected to be able to develop and innovate products, invest in technology and human resources, and increase productivity so that it has a positive effect on increasing the number of loans extended and banking income and net interest margin (NIM).

The BOPO ratio tested with the Wilcoxon test, and the test statistic value obtained -0.061 , this indicated there was no significant improvement in the BOPO performance after the acquisition compared to before the acquisition. The Wilcoxon test results explain that although there has been an improvement in the BOPO, which has decreased from 105.98 percent before the acquisition to 95.40 percent after the acquisition, the improvement is not statistically significant. The growth in the level of revenue or cost optimization that occurs after the acquisition is not large enough to be able to conclude a statistically significant improvement in the BOPO. With acquisitions, new investors tend to overhaul bank management, which is the preferred resource of shareholders who are already qualified and have extensive experience in the international and national banking world. The new management expected to be able to transform and improve bank operational performance, which includes improvements in risk and human resource management, technology investment, revenue growth, and cost optimization.

Loan to Deposit Ratio (LDR) is a measure of liquidity ratio, which is the ratio of loans disbursed and third party funds collected. The LDR ratio of the combined samples was tested with two paired samples to analyze the difference before and after the acquisition, and the test result obtained t-value 2.688 at a one percent significance level. However, the LDR after the acquisition is higher than before the acquisition. This result is different from the hypothesis. The average bank LDR after the acquisition increased to 98.80 percent from before the acquisition of 77.78 percent. This result shows that there is a real difference in the LDR liquidity ratio of the acquired banks between after and before the acquisition. After the acquisition, the bank has lower liquidity than before the acquisition; this happened because the injection of capital from new shareholders strengthens the bank's capital structure so that banks become more expansive in channeling credit. Loan to Deposit Ratio is a variable that can represent the ability of banks to carry out their functions, namely channeling funds (in the form of credit) to the public. After the acquisition, the ability of banks to extend credit is better than before the acquisition.

The commitment gap has two components, namely the commitment receivables component and the commitment liabilities. Commitment receivables represent receipts (receivables), which in the future are likely to be obtained by banks. Commitment liabilities are liabilities (expenses), which in the future have the opportunity to be issued by the bank. The lower the difference between commitment receivables and commitment liabilities, the risk level owned by banks will be lower. The difference in commitment gap before and after acquisition in the combined sample tested with the Wilcoxon test, and the test statistic value obtained -3,619 significant at one percent significant level, where the commitment liabilities before the acquisition was lower than after acquisition. These statistical test results indicate that after the acquisition, the bank has higher market risk sensitivity than before the acquisition.

\subsection{Differences in Financial Performance after vs. Before Cross-Border Acquisition}

The different test results in Table 3 showed that asset quality (NPL) performance, compliance with regulatory requirements (GWM), liquidity (LDR), and sensitivity to market risk (Commitment Gap) after acquisition has changed. The ratio of the reserve requirement, LDR, and the Commitment Gap value after acquisition has increased, while the NPL ratio has decreased. All changes in the variables used in the test differ according to the hypothesis used, except for the LDR ratio and Commitment Gap. 
Table 3 Different the performance of cross-border acquisition after and before the acquisition

\begin{tabular}{|c|c|c|c|c|c|c|}
\hline \multirow{2}{*}{ Variable } & \multicolumn{2}{|c|}{ Mean } & \multirow{2}{*}{ Mean gap } & \multirow{2}{*}{ t-value } & \multirow{2}{*}{ p-value } & \\
\hline & After & Before & & & & \\
\hline CAR (\%) & 25.92 & 22.29 & 3.63 & 0.701 & 0.248 & \\
\hline NPL (\%) & 3.07 & 5.29 & -2.22 & -1.528 & 0.075 & $*$ \\
\hline GWM (\%) & 9.41 & 7.13 & 2.28 & 2.14 & 0.026 & $* *$ \\
\hline ROE (\%) & 3.85 & 0.54 & 3.31 & 0.612 & 0.276 & \\
\hline NIM (\%) & 4.88 & 5.33 & -0.45 & -1.048 & 0.157 & \\
\hline BOPO (\%) & 93.64 & 101.23 & -7.59 & -0.982 & 0.172 & \\
\hline LDR (\%) & 107.62 & 74.57 & 33.05 & 2.849 & 0.007 & $* * *$ \\
\hline GAP (IDR mn) & -6641321.97 & -645360.91 & -5995961.06 & -2.554 & 0.012 & $* *$ \\
\hline
\end{tabular}

Note: all variables use the paired sample t-value.

Significant at the $\alpha$ level:*10 percent, ${ }^{* *} 5$ percent, and ${ }^{* * *} 1$ percent.

Test results produce a test statistic value of 0.701 or there is no significant difference in the capital adequacy ratio or CAR after the acquisition compared to before the acquisition. Although the results of descriptive statistics mean the average CAR ratio after the acquisition is higher than before the acquisition, but these results are not significantly different. Compared to the other two sample groups, namely the combined sample and the domestic acquisition target bank, only the sample of foreign target acquisition banks has insignificant results. Referring to the results of the descriptive statistical analysis, the average CAR ratio after foreign acquisition increased by only three percent, in contrast to the domestic acquisition target bank group that experienced an increase in CAR ratio of up to 11.8 percent after the acquisition. These results show that the bank's target for a previous foreign acquisition to have sufficient capital or CAR so that capital injection from new investors does not have a significant effect on increasing capital adequacy.

The NPL ratios show that results of two paired-sample tests at foreign acquisition target banks show the results of statistical value -1.528 , significant at a ten percent significant level, where the NPL ratio after acquisition has a lower value than before the acquisition. This understanding supported by the results of descriptive statistics, where after the acquisition, there was a decline in the NPL ratio from 5.29 to 3.07 percent. Different test results and descriptive statistics support the hypothesis. After the acquisition of new management with the support of shareholders, they make strategic efforts to improve credit quality, for example, by writing off loans from write-ups, selling off bad assets, monitoring closely, and preventing/anticipating loans channeled by applying early warning signals, and problem loans restructuring. In some instances, foreign investors can bail out non-performing loans through a particular company or Special Purpose Vehicle (SPV).

The reserve requirement ratio shows management or compliance aspects with the regulatory requirements. The reserve requirement ratio shows the results of the test statistic value of 2.140 and is a significant level at five percent. These results indicate a significant improvement in the reserve requirement after the acquisition compared to before the acquisition. Descriptive statistics also show the same thing, where after the acquisition, the average reserve requirement increased to 9.41 percent, whereas before the acquisition, the value reached 7.13. The results of the different statutory reserve ratios at foreign acquisition target banks are similar to the results of the combined sample tests, where the results of the different tests are significant level at 5 percent.

A significant increase in Statutory Reserves occurred because, after the acquisition of the bank, the acquisition succeeded in increasing the total of third party funds that had collected through savings product innovations that were more attractive to depositors. Also, foreign investors tend to have a high level of compliance with regulations set by a country's regulator, especially those that occur in Indonesia. These are the reasons why the reserve requirement of foreign acquisition banks increases after the acquisition.

Based on two paired-sample test results, the statistical value of the test is 0.612 , or there is no significant difference between the performance of the ROE ratio after and before foreign acquisitions, even though the descriptive statistical results 


\title{
International Journal of Business and Applied Social Science
}

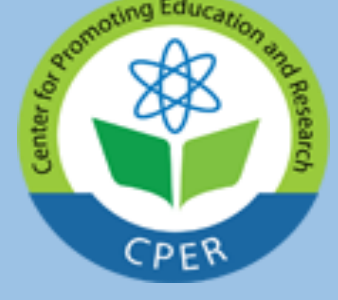

\author{
E-ISSN: 2469-6501 \\ VOL: 6, ISSUE: 3 \\ March/2020
}

DOI:10.33642/ijbass.v6n3p5

https://ijbassnet.com/

show an increase in ROE performance in a sample of banks targeting foreign acquisitions. The different test results on this sample of foreign acquisition target banks are similar to the results on the other two sample groups, namely the combined sample and the domestic target acquisition bank. The increase in net profit that occurred in foreign acquisition banks after the acquisition was not as fast as the increase in capital that had occurred before. Foreign acquisition banks are not optimal in using additional capital from shareholders.

The NIM ratio after the acquisition is also not significantly different from the NIM ratio before the acquisition, where the test statistic is -1.048 . The results of descriptive statistical analysis show a decrease of 0.45 percent at the time after the foreign acquisition (before the acquisition of the NIM ratio reached 5.33 percent), but based on the results of different test values after and before the foreign acquisition has no difference. Compared to the other two sample groups, only the sample of the cross-border acquisition bank is insignificant, whereas, in the other two sample groups (combined and domestic samples), the test results are significantly different at the $\alpha$ one percent level.

The decline in NIM of foreign acquisition banks was relatively low so that it was not significantly different after the acquisition compared to before the acquisition because it had a more extensive low-interest third party deposit base that was stable enough to withstand the fluctuation in the interest rate that occurred. Injection of funds from new shareholders partly used for investment in low-interest savings products such as innovative savings and current accounts, and training and developing a better sales force.

The results test show the statistical value of the test -0.982 and there is no significant difference even though descriptive statistical analysis on foreign acquisition bank samples shows a decrease in the BOPO ratio after the acquisition, where the BOPO ratio before and after the acquisition respectively is 101.23 percent and 93.64 percent (difference by 7.59 percent). The results of the different BOPO ratio tests in the sample bank of the foreign acquisition target are also in line with the results of the other two sample groups, there is no significant difference in the reduction in the BOPO ratio after and before the acquisition.

The results test for the LDR ratio for cross-border acquisition samples shows a statistical test value of 2.849, significant at one percent significant level. This result means that after the acquisition of foreign investors, LDR increased than before the acquisition. The increase occurred affected the liquidity risk after the acquisition. This result is in line with descriptive statistics where the LDR value after acquisition increased from 74.57 percent to 107.62 percent. These results are similar to the results of the different tests belonging to the combined sample, where the ratio after acquisition in the combined sample is also higher than before the acquisition and significant at the 99 percent significance level.

The Commitment Gap results in illustrating that generate a statistical value of -2.554 , significant at a significant level 5 percent. The calculation results show a drastic decrease in the commitment gap (higher commitment liabilities) in the sample of foreign acquisition banks, where the commitment gap after the acquisition reached 10.29 times compared to before the acquisition. This resulted in a higher sensitivity to market risk after the acquisition.

\subsection{Differences in Financial Performance after vs. Before the Acquisition at the Domestic Acquisition Bank}

The test results on domestic acquisition show that the performance of the CAR, NPL, NIM, and Commitment Gap variables after the acquisition experienced significant changes. The CAR ratio after acquisition has increased, while the NPL, NIM, and Gap Commitment values have decreased. The results of tests following the hypothesis used two variables (CAR, NPL), but the NIM ratio and Commitment Gap of the results of different tests shows the opposite.

In the CAR ratio of banks for domestic acquisition sample, the test results obtain a statistic value of 2.094 and significant at the 5 percent level $(\alpha)$, where the CAR significantly increases by 11.78 percent from an average of 16.52 percent before the acquisition becomes an average of 28,3 percent after the acquisition. The different test results on this sample of domestic target acquisition banks are consistent with the results on the combined sample, where the CAR ratio after the acquisition increased significantly at 95 percent confidence intervals. The average domestic acquisition bank has a relatively low CAR ratio due to capital constraints making it difficult to grow. Capital injection from new shareholders expected to increase growth and the ability of banks to deal with the risk of bad credit and other operational losses. 
E-ISSN: 2469-6501

VOL: 6, ISSUE: 3

March/2020

DOI:10.33642/fjbass.v6n3p5

https://ijbassnet.com/

(C) Center for Promoting Education and Research (CPER) USA

WwW.cpernet.org

Table 4 Statistical tests on the performance of domestic acquisition banks after and before the acquisition

\begin{tabular}{lrrrrrr}
\multirow{2}{*}{ Variabel } & \multicolumn{2}{c}{ Mean } & \multicolumn{2}{c}{ Difference } & t-value & p-value \\
\cline { 2 - 6 } & \multicolumn{1}{c}{ After } & \multicolumn{1}{c}{ Before } & & & & \\
\hline CAR (\%) & 28.3 & 16.52 & 11.78 & 2.094 & 0.035 & $* *$ \\
NPL (\%) & 3.8 & 9.12 & -5.32 & -1.572 & 0.078 & $*$ \\
GWM (\%) & 8.22 & 7.42 & 0.8 & 0.529 & 0.306 & \\
ROE (\%) & 0.22 & -2.59 & 2.81 & 0.430 & 0.340 & \\
NIM (\%) & 5.05 & 7.25 & -2.2 & -2.940 & 0.001 & $* * *$ \\
BOPO (\%) & 98.13 & 113.37 & -15.24 & -0.852 & 0.210 & \\
LDR (\%) & 85.07 & 82.79 & 2.28 & 0.552 & 0.298 & \\
& -1482818.73 & -1205107.51 & - & & & $*$ \\
GAP (IDR mn) & & & 277711.22 & -1.691 & 0.065 & \\
\hline
\end{tabular}

Note: all variables use the paired sample t-value.

Significant at the $\alpha$ level:*10 percent, ${ }^{* *} 5$ percent, and ${ }^{* * *} 1$ percent.

In the NPL ratio of banks for the domestic acquisition sample, the test results obtain a statistic value of -1.572 and significant at the 10 percent level $(\alpha)$, and NPL decreases by 5.32 percent from 9.12 percent before acquisition to 3.80 percent after the acquisition. Similar to foreign acquisition target banks, the results of the t-tests in the two groups of target acquisition banks are significant at the same level ( $\alpha$ on ten percent), but different in the combined sample (significant results at the $\alpha$ on five percent level).

In the domestic acquisition sample, the t-value results obtain a test statistic value of 0.529 ; there is no significant increase in the reserve requirement ratio after the acquisition compared to before the acquisition. The average reserve requirement after the acquisition only increased by 0.8 percent from 7.42 percent before the acquisition to 8.22 percent after the acquisition. The t-test results at this domestic acquisition target bank differ from the other two sample groups (combined and foreign target acquisition banks), both of which have positive results, where the ratio after the acquisition is higher than before acquisition, and the results are significant at the $\alpha$ level at 5 percent.

The $t$-value results obtain a statistical test value of 0.430 and an increase in ROE that occurs after the acquisition of 2.81 percent is not significant. The average ROE after acquisition reached 0.22 percent, increasing from -2.59 before the acquisition. The results of the different values in the domestic acquisition bank group are similar to the results of the different ROE ratio tests in the other two samples, where the other two samples have insignificant results.

The t-value results obtain a statistical test value of -2.940 and significantly at a significant $\alpha$ level at one percent. However, this result is different from the hypothesis used for the NIM ratio, namely the NIM ratio after the acquisition is higher than before acquisition. The average NIM after acquisition decreased from 7.25 percent before the acquisition, to 5.05 after the acquisition. These results are similar to the combined bank sample, both in terms of the negative relationship and the level of significance in the t-test outputs.

The results of the paired $t$-value results in a statistical value of -0.852 , a decrease in the BOPO ratio after the acquisition compared before the acquisition is not significant. The average decrease in the BOPO ratio after the acquisition of a sample of domestic acquisition target banks reached 15.24 percent. Different tests in the other two sample groups (combined and foreign) also showed similar results, which were not significant.

The hypothesis in the LDR ratio is that there is a significant decrease after the acquisition. The t-test results obtain a statistical value of 0.552 and there is no significant change between the LDR ratio after the acquisition and before acquisition in a sample of domestic acquisition target banks. The average LDR of domestic acquisition target banks after the acquisition increased by 2.28 percent to $85.07 \%$, from before the acquisition of 82.79 percent. Compared to the two sample groups (combined and foreign), only the results of the statistical tests on the sample of domestic bank targets for acquisition were not significant. 
E-ISSN: 2469-6501

VOL: 6, ISSUE: 3

March/2020

The t-value results obtain a statistical value of -1,691 and are significant at the $\alpha$ level at ten percent. Increase in the net commitment liabilities after the acquisition reached more than 20 percent. This resulted in a higher increase in the sensitivity to market risk.

\section{Conclusions}

The bank's financial performance showed improvement was in both groups of foreign and domestic acquisition banks; there was an improvement in credit quality where the NPL ratio decreased. At the cross-border acquisition, there was an improvement in management compliance with the regulatory rules where the minimum reserve requirement increased significantly compared to before the acquisition. At the domestic acquisition bank, there was an improvement with a significant increase in the capital adequacy ratio; however, this did not happen to cross-border acquisition. Nevertheless, there was a significant decrease in net interest margin and liquidity, respectively for domestic and cross-border acquisition banks. The sensitivity to market risk significantly increased for domestic and cross-border acquisition banks.

\section{References}

Aprilita I, Tjandrakirana R, Aspahani H. 2013. Comparative analysis of the company's financial performance before and after the acquisition (study of acquirer companies listed on the Indonesia Stock Exchange for the period 2000-2011). Sriwijaya Business and Management Journal. 11 (2): 99-114.

Al-Hroot YAK, Mssadeh AAD, Amireh MSL, Othman MDH. 2017. An empirical analysis of pre- and post-merger impacts on financial performance: a case study from Jordan Bank Expert. International Journal of Information, Business and Management. 9 (3): 215-228.

Al-Qudaiby B, Muhammad KR. 2014. Financial synergy in mergers and acquisitions. Evidence from Saudi Arabia. The IEB International Journal of Finance. 9: 182-199.

Amelia F, Ika SR. 2014. Bank performance in Indonesia after mergers and acquisitions with foreign ownership: is it better?. Effective Journal of Business and Economics. 5 (1): 73-84.

Anthony M. 2017. Effects of mergers and acquisitions on financial performance case studies of commercial banks. International Journal of Business Management \& Finance. 1 (6): 93-105.

Cahyarini I, Pustikaningsih A. 2017. Analysis of differences in the company's financial performance before and after mergers and acquisitions (empirical study on merger and acquisition companies listed on the Indonesia Stock Exchange for the period 2012-2014). Profita Journal. 7: 1-15.

Coyle B. 2000. Corporate Finance: Mergers \& Acquisitions. Chicago (US): Fitzroy Dearborn Publishers.

Gandapradja P. 2004. Basis and Principles of Bank Supervision. Jakarta (ID): PT Gramedia Pustaka Utama.

Fauzi YY. 2019. Banks are still sexy even though they are shrinking due to the era of high bank interest. [Internet]. [Downloaded 2019 August 27]. Available at https://www.cnnindonesia.com/ekonomi/20190102072656-78357844/ bank-remains-sexy-although-profit-shrinkage-effects-era-high-interest

Hang HTT, Vy PD, Bandaralage J. 2016. Mergers, acquisitions and market concentration in the banking sector: The case of Vietnam. Asian Journal of Economics and Empirical Research. 3 (1): 49-58.

Leonita L. 2017. Will foreigners add value to the financial industry in Indonesia?. Journal of Business Management and Entrepreneurship. 1 (2): 65-75.

Marzuki MA, Widyawati N. 2013. Financial performance before and after the acquisition: Study at PT Bank CIMB Niaga. Journal of Management Science and Research. 1 (2): 222-238.

Mulyana B. 2012. Mergers and acquisitions of banks in Indonesia in 1995-2008. [Dissertation] Bogor (ID): Bogor Agricultural University.

Pradipta H, Zaharias B. 2016. Assessment of the impact of mergers and acquisitions on banking efficiency, analysis before and after mergers and acquisitions. Journal of Economics and Development. 24 (2): 85-95. 
E-ISSN: 2469-6501

VOL: 6, ISSUE: 3

March/2020

DOI:10.33642/fjbass.v6n3p5

https://ijbassnet.com/

CCenter for Promoting Education and Research (CPER) USA

WWW.cpernet.org

Sufian F, Majid MZA. 2007. Bank mergers performance and the determinants of Singaporean banks' efficiency: an application of two-stage banking models. Gadjah Mada International Journal of Business. 9 (1): 19-39.

Sufian F, Muhamad J, Ariffin ANB, Yahya MH, Kamarudin F. 2012. Assessing the effects of mergers and acquisitions on revenue efficiency: evidence from the Malaysian banking sector. SAGE Publications. 16 (1): 1-11.

Tripathi V, Lamba A. 2015. What drives cross-border mergers and acquisitions? A study of Indian multinational enterprises. Journal of Strategy Management. 8 (4): 384-414.

Weston JF, Weaver SC. 2001. Mergers and Acquisitions.. New York (US): McGraw Hill.

Tandra JK. 2017. Financial performance of PT Bank Rakyat Indonesia Agroniaga, Tbk. before and after it was acquired by PT Bank Rakyat Indonesia (Persero), Tbk. FinAcc Journal. 1 (11): 2005-2016. 